\title{
Correlation of mRNA for oestrogen receptor beta splice variants ERß1, ERß2/ERßcx and ERß5 with outcome in endocrine-treated breast cancer
}

\author{
M P A Davies, P A O'Neill, H Innes, D R Sibson, W Prime'1, C Holcombe ${ }^{2}$ and \\ C S Foster ${ }^{3}$
}

Clatterbridge Cancer Research Trust, J K Douglas Laboratories, Clatterbridge Hospital, Bebington, Wirral CH63 4JY, UK

${ }^{1}$ Cancer Tissue Bank Research Centre, University of Liverpool, Liverpool L69 3GA, UK

2Breast Services, Linda McCartney Centre, Royal Liverpool University Hospital, Prescot Street, Liverpool L7 8XP, UK

${ }^{3}$ Department of Cellular and Molecular Pathology, University of Liverpool, Liverpool L69 3GA, UK

(Requests for offprints should be addressed to M P A Davies; Email: Mike.Davies@ccrt.nhs.uk)

\begin{abstract}
This study has been performed to test the hypothesis that different oestrogen receptor beta (ER $\beta$ ) splice variants may be important determinants of clinical parameters, including outcome, in post-menopausal women with breast cancer receiving adjuvant endocrine treatment but no chemotherapy. Splice variants ER $\beta 1, E R \beta 2$ and ER $\beta 5$ have been analysed by semi-quantitative RT-PCR in a cohort of 105 patients with primary breast cancer. Clinical correlates included age, grade, size, nodal status, ER $\alpha$, progesterone receptor, Ki67, relapse-free survival (RFS) and overall survival (OS). Seventy per cent of cases were ER $\beta 1$ positive, $69 \%$ ER $\beta 2$ positive and 70\% ER $\beta 5$ positive. Within the cohort, $47 \%$ were positive for all three variants while $10 \%$ were negative for all three. ER $\beta 1$ exhibited no discernible relationship with disease outcome. ER $\beta 2$ and ER $\beta 5$ expression was significantly associated with better RFS $(P<0.005)$, and ER $\beta 2$ with better OS $(P=0.0002)$. In multivariate analysis, ER $\beta 2(P=0.006)$, nodal status and the level of Ki67 expression were independent predictors for RFS while ER $\beta 2(P=0.0008)$ and Ki67 status were independent predictors for OS. In the ER $\alpha$-positive cases, or in the subset of those receiving adjuvant tamoxifen, ER $\beta 2$ was significantly associated with good RFS $(P<0.0005)$ and was the only independent marker of OS. We conclude that precise identification of splice variants of ER $\beta$ are more important assessors than is ER $\beta 1$ alone of the biological status of individual breast cancers, and hence in predicting their response to endocrine therapy.
\end{abstract}

Journal of Molecular Endocrinology (2004) 33, 773-782

\section{Introduction}

Oestrogen receptor alpha $(\mathrm{ER} \alpha)$, as a measure of steroid hormone receptor status, is a currently accepted prognostic marker used to predict the response of an individual breast cancer to hormone therapy (Pertschuk \& Axiotis 1999). However, it is known that up to $40 \%$ of breast tumours with positive $\mathrm{ER} \alpha$ status do not respond to endocrine therapy (Locker 1998). Reasons for this lack of response are poorly understood. However, the relative expression of $\operatorname{ER} \beta$ may be an important modulator of oestrogenic hormone manipulation. A variety of studies have employed RT-PGR or in situ hybridisation to analyse the mammary expression of ER $\beta$ mRNA (Enmark et al. 1997, Vladusic et al. 1998, Dotzlaw et al. 1999, Leygue et al. 1999, Speirs et al. 1999a, Iwao et al. 2000a,b, Kurebayashi et al. 2000, Bieche et al. 2001, Cullen et al. 2001, de Cremoux et al. 2002, Omoto et al. 2002, Tong et al. 2002). However, these studies are conflicting, reflecting either differences in case selection or limitations of the detection techniques. Nevertheless, it has been suggested that the level of ER $\beta$ expression has prognostic significance in breast cancer (Speirs et al. 1999a, Jarvinen et al. 2000, Knowlden et al. 2000, Speirs \& Kerin 2000, Mann et al. 2001, Fuqua et al. 2003). $\operatorname{ER} \beta$ has been 
associated with markers of low biological aggressiveness such as negative axillary nodal status (Jarvinen et al. 2000), low morphological grade (Jarvinen et al. 2000, Speirs \& Kerin 2000) and improved survival (Mann et al. 2001, Omoto et al. 2001). The ratio of $E R \alpha: E R \beta$ has been shown to predict progression to neoplasia and malignancy in the breast (Shaaban et al. 2003a) and the ratio ER $\alpha: E R \beta$ mRNA changes during mammary carcinogenesis (Leygue et al. 1998) together with relative amounts of different $\mathrm{ER} \beta$ variants (Leygue et al. 1999, Omoto et al. 2002).

$\mathrm{ER} \beta 1$, considered to be the full-length or wild-type $\operatorname{ER} \beta$, is able to form heterodimers with $\mathrm{ER} \alpha$ (Cowley et al. 1997) and in this may contribute to differences in ER-dependent gene expression. Some ER $\beta$ variants resulting from differential splicing are expressed in a cell-type and tissue-type specific manner (Saunders 1998), are expressed as proteins (Saunders et al. 2002) and can interact with both ER $\beta 1$ and ER $\alpha$ (Moore et al. 1998). Hence these splice variants may be considered as functionally distinct isoforms of ER $\beta$. For example, $\mathrm{ER} \beta 2$ (also known as $\mathrm{ER} \beta \mathrm{cx}$ ) is a variant that utilises an alternative exon 8 (Moore et al. 1998), a change that results in relatively poor binding to oestradiol and a dominant negative effect on ER $\alpha$ function (Ogawa et al. 1998). The putative ER $\beta 5$ protein sequence diverges from ER $\beta 1$ at the same point as ER $\beta 2$ (amino acid 469) by alternative splicing (Moore et al. 1998). As in ER $\beta 2$ the C-terminal of this ER $\beta 5$ protein is truncated, resulting in loss of the AF-2 core domain and differences in ligand binding (Peng et al. 2003). Such effects may modulate the action of therapies directed against $\mathrm{ER} \alpha$, such as the endocrine treatments used in breast cancer. Expression of $\operatorname{ER} \beta$ variants has been shown to vary between different tumours and cell lines (Leygue et al. 1999, Iwao et al. 2000a,b, Omoto et al. 2002, Tong et al. 2002). However, expression of individual splice variants is not known with respect to particular clinical parameters, including treatment or outcome, principally because many mRNA studies utilised RT-PGR primers designed against sequences common to all splice variants (Leygue et al. 1998, Dotzlaw et al. 1999, Speirs et al. 1999a,b, Iwao et al. 2000a,b, Knowlden et al. 2000, Kurebayashi et al. 2000, Bieche et al. 2001, Cullen et al. 2001, de Gremoux et al. 2002) and variant-specific antibodies have not been widely available. Levels of mRNA for ER $\beta 2$ and ER $\beta 5$ are recognised to be higher than those for the ER $\beta 1$ variant (Leygue et al. 1999, Iwao et al. $2000 a, b)$, hence many of the non-specific RT-PCR studies to date may reflect expression of these variants. It is therefore important to determine the individual relationships between $\operatorname{ER} \beta$ variants and clinical and pathological factors, so as to understand better their relative contributions to breast disease. To this end, we have analysed a retrospective cohort of primary breast cancers, representing a series of cases receiving endocrine therapy but not chemotherapy. Typically such clinically defined cohorts are heterogeneous, allowing associations with other pathological factors to be considered, but requiring that multivariate statistical analysis be applied when considering outcome data.

The literature contains detailed consensual reference to $\operatorname{ER} \beta$ splice variants $\operatorname{ER} \beta 1, E R \beta 2 /$ $\mathrm{ER} \beta \mathrm{cx}$ and $\mathrm{ER} \beta 5$, including the agreed primer sequences for PGR. Although not exhaustive, analysis of these three splice variants is sufficient to identify those splice variants commonly expressed by normal breast and breast carcinomas. Therefore, the purpose of the present study was to test the hypothesis that $\mathrm{ER} \beta$ splice variant expression in breast cancer is related to patient outcome data when patients receive only endocrine therapy in the absence of chemotherapy.

\section{Materials and methods}

\section{Subjects}

Patients undergoing treatment, at the Royal Liverpool University Hospital, for invasive breast cancer during the period 1993-1999 were identified by the Cancer Tissue Bank Research Centre (CTBRG). Tissues were collected by CTBRC with full consent and appropriate ethical committee approval and RNA was prepared by standard methods. Clinical follow-up data were recorded by retrospective case-note review, but were unavailable for some variables in a limited number of cases. All cases were subjected to histopathological review according to the guidelines of the UK NHSBSP (National Coordinating Group for Breast Screening Pathology 1997), by three investigators (P A O'N, C S F and Prof. J P Sloane). Histopathological sections of tissues adjacent to that used for 
Table 1 Histological, clinical and molecular characteristics of 105 breast cancer cases receiving adjuvant endocrine treatment but no chemotherapy with outcome data: RFS and OS. Log-rank $P$ values are from Kaplan-Meier analysis, hazard ratios (with 95\% confidence intervals $(\mathrm{Cls})$ ) and multivariate $P$ values are from Cox's regression analysis

\begin{tabular}{|c|c|c|c|c|c|c|}
\hline & Group & $n$ & $\begin{array}{l}\text { Log-rank } \\
P \text { value }\end{array}$ & $\begin{array}{l}\text { Hazard ratio } \\
(95 \% \mathrm{Cl})\end{array}$ & $\begin{array}{l}\text { Multivariate } \\
\boldsymbol{P} \text { value }\end{array}$ & $\begin{array}{l}\text { Poor outcome } \\
\text { associated with }\end{array}$ \\
\hline \multirow{2}{*}{$\begin{array}{l}\text { Characteristic } \\
\text { Histology }\end{array}$} & & & & & & \\
\hline & $\begin{array}{l}\text { Invasive ductal } \\
\text { Other }\end{array}$ & $\begin{array}{l}86 \\
19\end{array}$ & 0.035 OS & $0.35(0.13-0.97)$ OS & $\underline{\mathrm{NS}}$ & Invasive ductal \\
\hline \multirow[t]{3}{*}{ Surgery } & Wide local & & & & & \\
\hline & excision & 63 & NS & NS & NS & - \\
\hline & Mastectomy & 42 & - & - & - & - \\
\hline \multirow[t]{2}{*}{ Radiotherapy } & No & 55 & NS & NS & NS & - \\
\hline & Yes & 49 & - & - & - & - \\
\hline \multirow[t]{3}{*}{ Grade } & I & 18 & 0.005 RFS & $2 \cdot 0(1 \cdot 3-3 \cdot 0)$ RFS & NS & Higher grade \\
\hline & II & 42 & 0.018 OS & $1 \cdot 8(1 \cdot 2-2 \cdot 8)$ OS & - & \\
\hline & III & 45 & - & - & - & \\
\hline \multirow[t]{3}{*}{ Size } & $U p$ to $2 \mathrm{~cm}$ & 38 & 0.038 OS & $1 \cdot 9(1 \cdot 0-3 \cdot 6)$ OS & NS & Size $>2 \mathrm{~cm}$ \\
\hline & $2-5 \mathrm{~cm}$ & 60 & - & - & - & \\
\hline & $5 \mathrm{~cm}$ and up & 5 & - & - & - & \\
\hline \multirow[t]{2}{*}{ Nodal status } & Negative & 47 & 0.0002 RFS & $3.4(1.7-6 \cdot 8)$ RFS & 0.003 RFS & Node positive \\
\hline & Positive & 42 & 0.011 OS & $2 \cdot 3(1 \cdot 2-4 \cdot 5)$ OS & - & \\
\hline \multirow[t]{2}{*}{$\mathrm{ER} \alpha$} & Negative & 37 & 0.0002 RFS & $0.35(0.20-0.63)$ RFS & NS & ER negative \\
\hline & Positive & 65 & $0.008 \mathrm{OS}$ & $0.46(0.26-0.83)$ OS & - & \\
\hline \multirow[t]{2}{*}{ PgR status } & Negative & 49 & 0.022 RFS & $0.49(0.26-0.91)$ RFS & NS & PgR negative \\
\hline & Positive & 42 & 0.043 OS & $0.53(0.28-0.99)$ OS & - & \\
\hline \multirow[t]{2}{*}{ Ki67 status } & Low & 44 & 0.0002 RFS & $3 \cdot 3(1 \cdot 7-6 \cdot 2)$ RFS & 0.0004 RFS & High Ki67 \\
\hline & High & 45 & 0.002 OS & $2 \cdot 7(1 \cdot 4-5 \cdot 3)$ OS & $0.003 \mathrm{OS}$ & \\
\hline \multirow[t]{2}{*}{ ER $\beta 1$ RT-PCR } & Negative & 32 & NS & NS & NS & - \\
\hline & Positive & 73 & - & - & - & \\
\hline \multirow[t]{2}{*}{ ER $\beta 2$ RT-PCR } & Negative & 33 & $<0.0001$ RFS & $0.31(0.17-0.56)$ RFS & 0.006 RFS & $\mathrm{ER} \beta 2$ negative \\
\hline & Positive & 72 & 0.0002 OS & $0.35(0.20-0.62)$ OS & 0.0008 OS & \\
\hline \multirow[t]{2}{*}{ ER $\beta 5$ RT-PCR } & Negative & 31 & 0.005 RFS & $0.45(0.25-0.79)$ RFS NS & ER $\beta 5$ negative & \\
\hline & Positive & 74 & - & - & - & \\
\hline
\end{tabular}

RNA preparation were assessed and cases comprising at least $50 \%$ tumour cells were included $(90 \%$ of such cases contained $75 \%$ or more tumour cells). Cases were only included if the quality of the prepared cDNA was considered adequate (see below). Consequent upon these caveats, the study population (Table 1) comprised 105 post-menopausal women treated with surgery, either with or without radiation treatment and no chemotherapy. The median age was 68 years (range 48-88). Most cases were invasive ductal carcinomas of no special type. Other invasive carcinoma types included lobular $(n=10)$, mucinous $(n=4)$, medullary $(n=1)$, papillary $(n=1)$, tubular $(n=1)$, metaplastic $(n=1)$ and mixed mucinous/papillary $(n=1)$.

All patients received adjuvant hormone therapy but no chemotherapy. For 89 of the cases, endocrine therapy comprised only adjuvant tamoxifen; adjuvant treatment for seven further patients was received as part of the Arimidexor Tamoxifen Alone or in Combination (ATAC) trial and could not be determined. Only nine patients received primary tamoxifen therapy prior to surgery, six of these patients then received adjuvant tamoxifen and three received adjuvant anastrozole. Hence surgical specimens for all but these nine cases were collected prior to commencement of endocrine therapy. Since routine histopathology did not include steroid receptor analysis until 1996, some cases were subsequently found to be $\mathrm{ER} \alpha$ negative.

Ethical approval for this study was obtained from all relevant bodies.

\section{Immunostaining}

Immunostaining data for $\mathrm{ER} \alpha$, progesterone receptor $(\mathrm{PgR})$ and $\mathrm{Ki} 67$ were made available by the CTBRC. Briefly, a mouse anti-human ER $\alpha$ monoclonal antibody (Clone 1D5; Dako Ltd, Ely, 
Cambridge, UK) was used for the immunohistochemical detection of ER $\alpha$. PgR status was assessed using a mouse monoclonal anti-PgR antibody (Clone 1A6; Novacastra, Newcastle upon Tyne, UK) and Ki67 status was assessed using polyclonal rabbit anti-human Ki67 antibody (Ki67p; Novacastra). Formalin-fixed and paraffin waxembedded sections were immunostained by methods identical to those previously described (Shaaban et al. 2002, 2003b). To maximise consistency of scoring, only nuclei having moderate or strong staining were regarded as positive, independently of cytoplasmic staining. The percentage of nuclear-stained epithelial cells was calculated as a proportion of the total number of epithelial cells present. A 10\% cut-off was the conventional criterion to define $\mathrm{ER} \alpha$ staining, as previously described (Shaaban et al. 2002) and PgR staining. Staining for Ki67 was confirmed as high if $>20 \%$ cells stained (using a median cut-off from a larger cohort). Immunostaining data were unavailable for a limited number of cases.

\section{RT-PCR analysis}

Total RNA was provided by the GTBRC. Following a DNAaseI digestion step (Invitrogen), reverse transcription (RT) was performed in duplicate on $0.5 \mu \mathrm{g}$ RNA according to the manufacturer's instructions. RT reactions incorporated Superscript II Reverse Transcriptase (Invitrogen), $0.5 \mu \mathrm{g}$ Oligo $(\mathrm{dT})_{17}$ and $0.5 \mu \mathrm{l}$ Prime Recombinant Ribonuclease Inhibitor (Eppendorf, Cambridge, UK). Parallel reactions were performed in which the RT enzyme was omitted and these acted as controls for genomic DNA contamination.

PCR reactions $(20 \mu \mathrm{l})$ were performed in duplicate in 96-well plates, each using $2 \mu \mathrm{l}$ of a $1 / 20$ dilution of cDNA (equivalent to $\mathrm{cDNA}$ from approximately $2.5 \mathrm{ng}$ total RNA). PGR reactions included $0.2 \mathrm{mM}$ dNTPs, $0.5 \mathrm{U}$ HotstarTaq DNA polymerase (Qiagen) and $1 \times$ PCR Buffer (containing $1.5 \mathrm{mM} \mathrm{MgCl} 2$; Qiagen). Primer and $\mathrm{MgCl}_{2}$ concentrations varied as per Table 2 . The oligonucleotide primers (Table 2) for ER $\beta 1$ and $\operatorname{ER} \beta 2 / 5$ RT-PCR were taken from Moore et al. (1998). $\beta$-Actin and hypoxanthine ribosyltransferase (HPRT) were used as control genes for determination of RNA integrity and RT efficiency and positive controls (testis and MCF7 cells) were

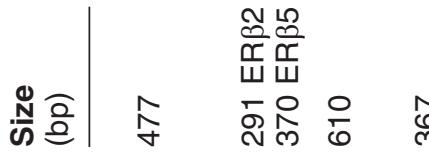

$\hat{\varrho}$

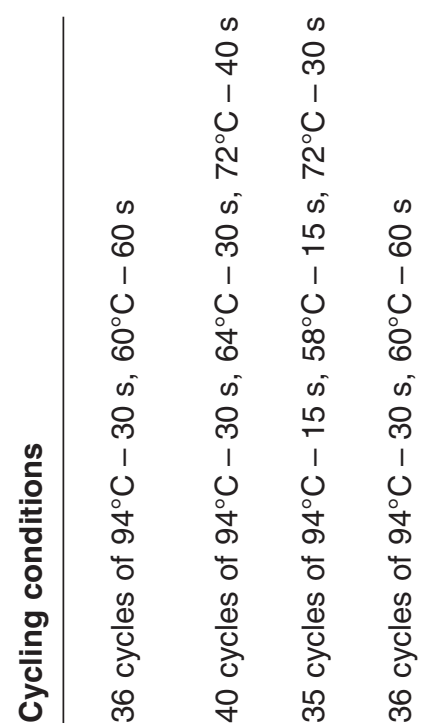
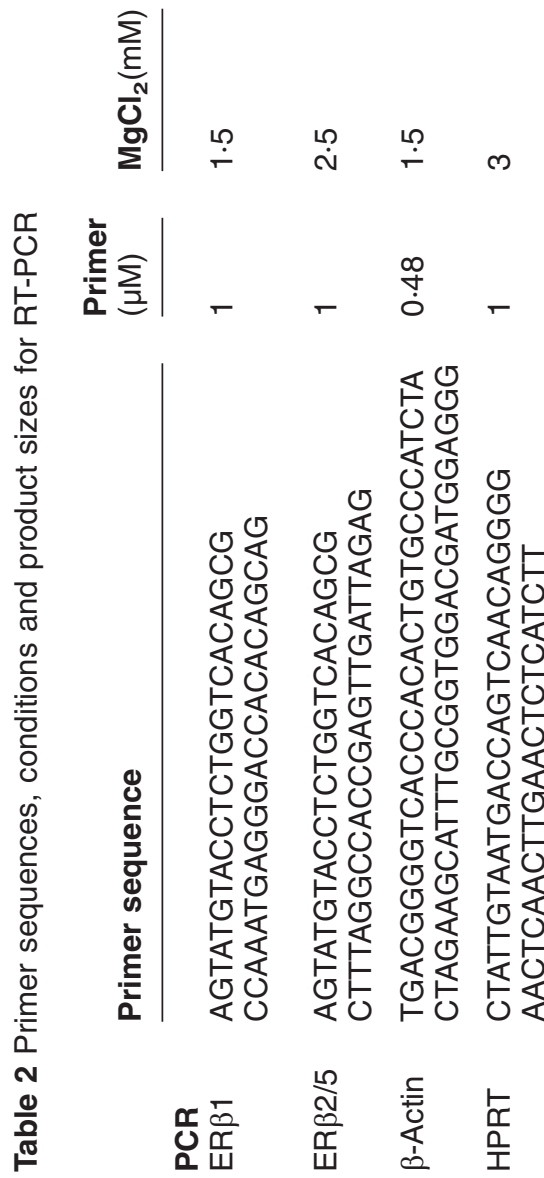
Table 3 Characteristics of 56 ER $\alpha$-positive breast cancer cases receiving only adjuvant tamoxifen treatment but no chemotherapy and no neoadjuvant treatment with outcome data: RFS and OS. Log-rank $P$ values are from Kaplan-Meier analysis, hazard ratios (with 95\% confidence intervals (Cls)) and multivariate $P$ values are from Cox's regression analysis

\begin{tabular}{|c|c|c|c|c|c|}
\hline & Group & $n$ & Log-rank $P$ value & Hazard ratio $(95 \% \mathrm{Cl})$ & Multivariate $P$ value \\
\hline \multicolumn{6}{|l|}{ Characteristic } \\
\hline \multirow[t]{3}{*}{ Grade } & I & 12 & 0.040 RFS & $2 \cdot 3(1 \cdot 2-4 \cdot 6)$ RFS & NS \\
\hline & II & 30 & 0.032 OS & $2 \cdot 3(1 \cdot 2-4 \cdot 3)$ OS & - \\
\hline & III & 14 & - & - & - \\
\hline \multirow{2}{*}{ Nodal status } & Negative & 29 & 0.011 RFS & $3 \cdot 5(1 \cdot 3-9 \cdot 7)$ RFS & 0.010 RFS \\
\hline & Positive & 21 & - & - & - \\
\hline \multirow[t]{2}{*}{ Ki67 status } & Low & 34 & 0.003 RFS & $3 \cdot 8(1 \cdot 5-9 \cdot 8)$ RFS & 0.003 RFS \\
\hline & High & 15 & - & - & - \\
\hline \multirow[t]{2}{*}{ ER $\beta 1$ RT-PCR } & Negative & 15 & NS & NS & NS \\
\hline & Positive & 41 & - & - & - \\
\hline \multirow{2}{*}{ ERß2 RT-PCR } & Negative & 16 & 0.0001 RFS & $0.17(0.06-0.46)$ RFS & 0.066 RFS \\
\hline & Positive & 40 & 0.0001 OS & $0.20(0.09-0.48)$ OS & 0.0004 OS \\
\hline \multirow[t]{2}{*}{ ERß5 RT-PCR } & Negative & 17 & 0.008 RFS & $0.32(0.13-0.78)$ RFS & NS \\
\hline & Positive & 39 & - & - & - \\
\hline
\end{tabular}

included. Each PCR reaction was limited in cycle number and/or primer concentration, so as to avoid the plateau phase of the reaction, but otherwise cycle number was maximised to give maximum sensitivity for each gene product. PCR was performed on Perkin Elmer 9600 thermal cyclers and all reactions (Table 2) included a $94{ }^{\circ} \mathrm{C} 13 \mathrm{~min}$ activation and a $72{ }^{\circ} \mathrm{C} 3$ min final extension.

PCR products were separated by electrophoresis on gels containing 2.5\% Seakem Agarose (Flowgen, Ashby de la Zouch, Leics, UK) and $40 \mathrm{mM}$ Trisacetate, $1 \mathrm{mM}$ EDTA, pH $7 \cdot 6$ buffer. Molecular mass markers (PhiX174/HaeIII; Abgene, Epson, Surrey, UK) were included on each gel and DNA was visualised by inclusion of $0.5 \mu \mathrm{g} / \mathrm{ml}$ ethidium bromide, scanning with a Molecular Dynamics FluorimagerSI and analysis with ImageQuant v. 4·1 (Amersham Biosciences). Control genes were scored as weak or strong positive and individual RT reactions excluded from ER $\beta$ assessment if either was negative, or if both were weak. Cases were considered positive for ER $\beta$ RT-PGR if any band was scored as positive by two independent investigators.

Identity of PCR products was confirmed by direct sequencing using DYEnamicET Dye Terminator Cycle Sequencing Kit for MegaBACE (Amersham Biosciences) and analysed on a MegaBACE1000 (Amersham Biosciences). Alternatively PCR products were cloned using TOPO-TA cloning (Invitrogen) prior to sequence analysis.

\section{Statistical analysis}

All statistical analyses were performed using the SPSS package (Windows, v. 11). To compare immunostaining percentage values in different groups, data were analysed by the non-parametric, two-sided Mann-Whitney test. Association between categorical data was assessed by the Chi-squared test, with contingency coefficients (Cont. Coeff.) calculated to assess the strength of different associations. Survival curves were generated using the Kaplan-Meier method for censored data and compared using the log-rank test. Cox's regression models were used to determine hazard ratios and for multivariate survival analysis.

\section{Results}

\section{RT-PCR}

The identities of representative RT-PGR products for each gene were confirmed by sequence analysis. No evidence of artefactual PGR products due to genomic DNA contamination was seen. The use of control genes $\beta$-actin and HPRT identified 105 cases in which cDNA was considered of appropriate quantity and integrity for further analysis. RT-PGR analysis of these 105 cases categorised $70 \%$ of cases $\mathrm{ER} \beta 1$ positive, $69 \% \mathrm{ER} \beta 2$ positive and $70 \% \mathrm{ER} \beta 5$ positive (Table 1) and these percentages were similar in the cohort of 56 ER $\alpha$-positive, adjuvant tamoxifen-only cases. A wide variety of expression 


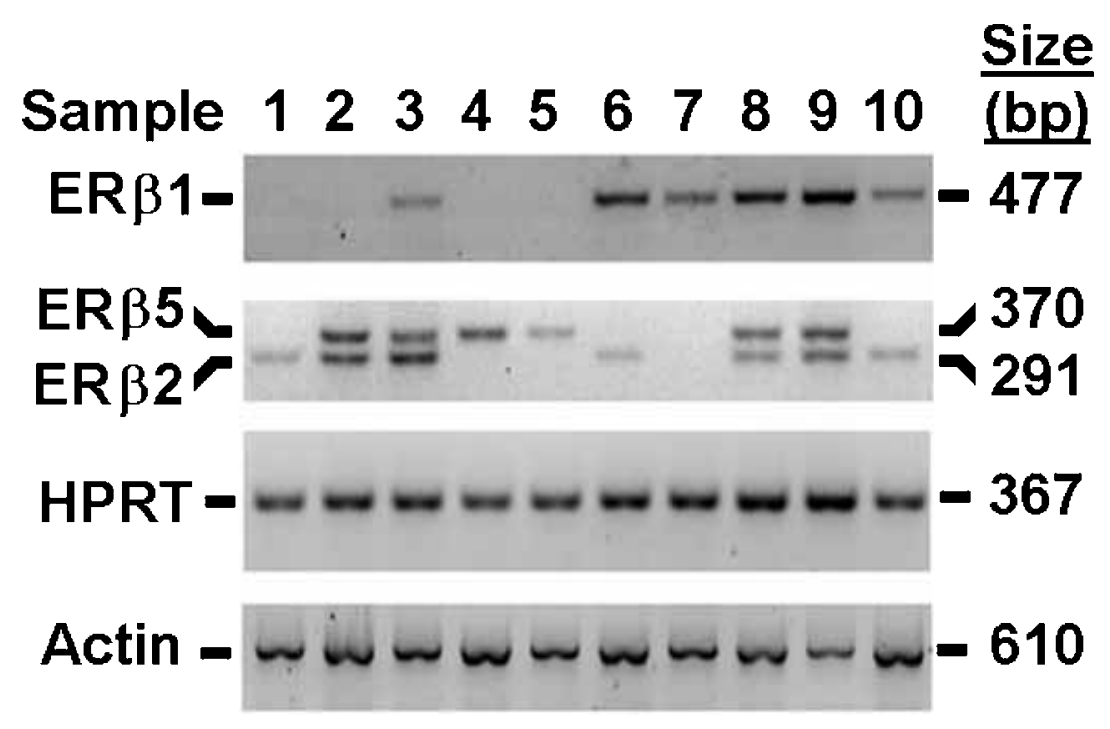

Figure 1 An example of RT-PCR results for selected breast cancer cases.

patterns was seen (Fig. 1). Nearly half of the cases (47\%) expressed all three splice variants and almost three-quarters expressed at least two variants $(72 \%)$. Strong relationships were identified between expression of all three mRNAs. However, based on Cont. Coeff. values ER $\beta 2$ and ER $\beta 5$ were more closely associated (Cont. Coeff. 0.45, $P=2 \times 10^{-7}$ ) than either variant was to $\operatorname{ER} \beta 1$ (ER $\beta 2$ Cont. Coeff. 0.24, $P=0 \cdot 01$; ER $\beta 5$ Cont. Coeff. 0.22, $P=0 \cdot 02$ ).

\section{Relationship of ERß RT-PCR with clinical and immunohistological parameters}

The relationships between each of the ER $\beta$ RT-PGR scores (ER $\beta 1, E R \beta 2, E R \beta 5)$ and the clinical and immunohistological parameters, presented in Table 1 were examined by the Chi-squared test. RT-PCR data for ER $\beta$ showed no association with any treatment groups, histology or tumour size. There was no association of any ER $\beta$ RT-PCR with ER $\alpha$, PgR or Ki67 staining and this was confirmed using a Mann-Whitney test for differences in staining strength (per cent positive cells) between RT-PCR-positive and -negative groups.

Some association was seen between ER $\beta 2$ and tumour grade; $E R \beta 2$ was positive in $89 \%$ of grade I, $52 \%$ of grade II and $76 \%$ of grade III tumours and RT-PGR-positive scores were significantly associated with grade I (Chi-squared, $P=0 \cdot 007$ ) or grade III (Chi-squared, $P=0 \cdot 024$ ) tumours as opposed to grade II tumours.

\section{Relationship of ER $\beta$ RT-PCR with disease outcome}

To examine the possible effect of $\mathrm{ER} \beta$ status in relation to endocrine treatment, outcome data have been restricted to those 105 women receiving endocrine treatment either with or without neoadjuvant tamoxifen treatment, but with no primary or adjuvant chemotherapy (Table 1). The median time to relapse for this cohort was 75.7 months (inter-quartile range 61.2-90.3) and the median time to death was 93.8 months (inter-quartile range 68.4-119.2). Subgroup analysis within this cohort was also carried out on the $65 \mathrm{ER} \alpha$-positive cases and the 56 ER $\alpha$-positive cases receiving adjuvant tamoxifen only (Table 3 ).

In the 105 case cohort, high grade, positivenodal status, larger size, ER $\alpha$-negative status, PgR-negative status and high Ki67 status were all associated with worse prognosis (Table 1). In addition, histopathological features other than invasive ductal carcinoma, were associated with a moderately better overall survival (OS) (Table 1). The choice of surgery, radiotherapy or endocrine treatment was of no significance for patient outcome. ER $\beta 2$ was associated with significantly better relapse-free survival (RFS) (Fig. 2) and OS 


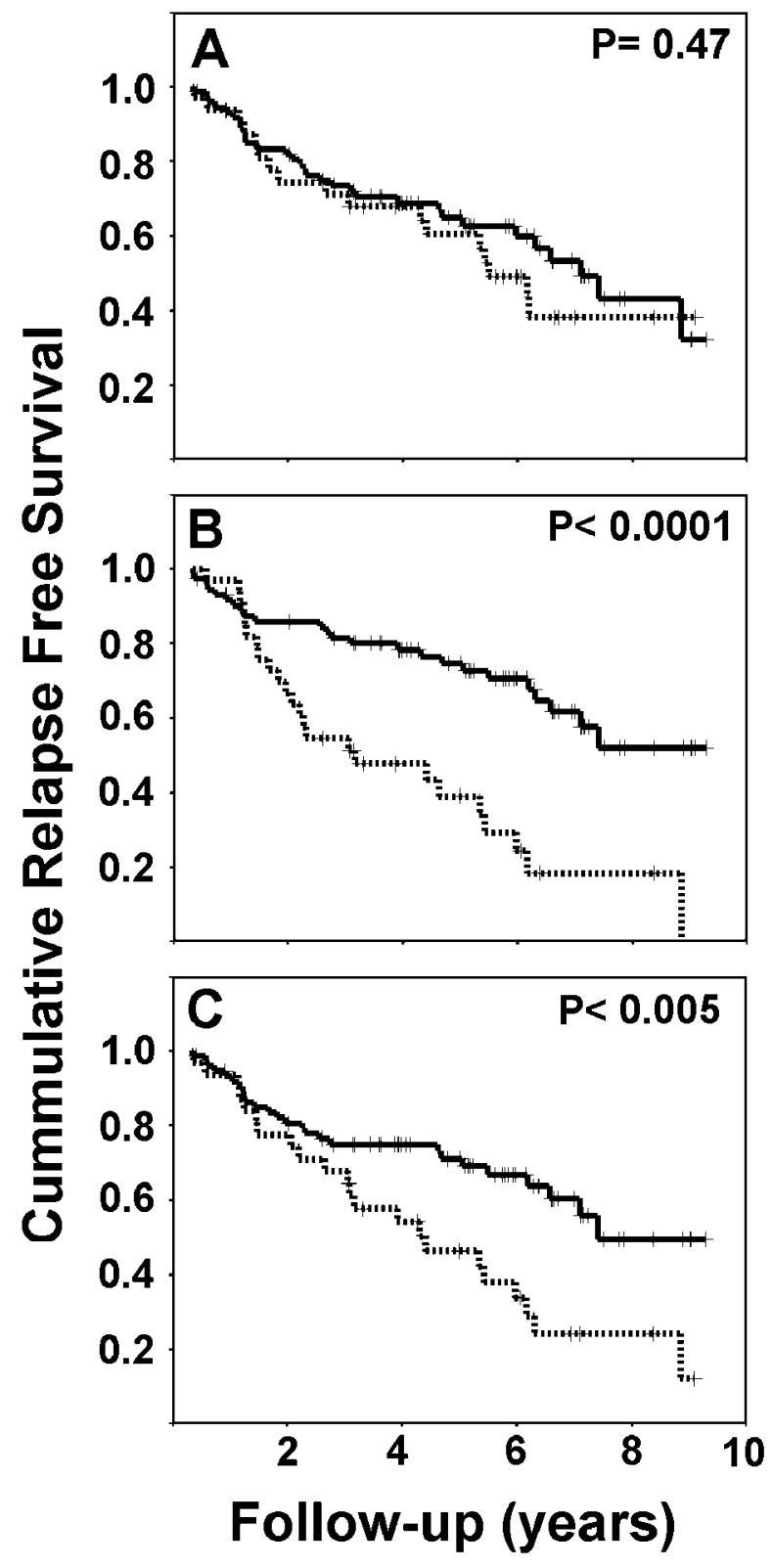

Figure 2 Kaplan-Meier plots of RFS for subgroups defined by RT-PCR status for ER $\beta 1$ (A), ER $\beta 2$ (B) and ER $\beta 5(C)$. Dotted lines are negative cases and unbroken lines positive cases, crosses represent censored data, $P$ values are given for log-rank tests.

(Table 1), while ER $\beta 5$ was also associated with better RFS. ER $\beta 1$ was not significantly associated with any measure of survival. For ER $\beta 2$-negative patients, the median time to relapse was $38 \cdot 1$ months (inter-quartile range $6 \cdot 6-69 \cdot 5$ ) and the median time to death was $51 \cdot 2$ months (inter- quartile range $32 \cdot 6-69 \cdot 8)$. In contrast, median time to either measure of outcome was not reached for ER $\beta 2$-positive cases. In multivariate analysis, nodal status $(P=0.003), \mathrm{Ki67}(P=0.0004)$ and $\mathrm{ER} \beta 2$ $(P=0.006)$ were independent markers of RFS and only Ki67 $(P=0.003)$ and $\operatorname{ER} \beta 2(P=0.0008)$ were independent markers of OS.

With respect to the ER $\alpha$-positive cases, irrespective of treatment $(n=65)$, the only significant markers for RFS are nodal status (log-rank $P=0.011), \mathrm{Ki} 67(P=0.039), \mathrm{ER} \beta 2(P<0.0001)$ and ERß5 $(P=0 \cdot 002)$. Of these, only nodal status $(P=0.011)$ and Ki67 $(P=0.028)$ are independently significant for RFS in multivariate analysis. For OS, grade $(P=0.033), \quad \mathrm{ER} \beta 2 \quad(P=0.0001)$ and ER $\beta 5(P=0 \cdot 042)$ are significant by log-rank, but only $\operatorname{ER} \beta 2$ is independent in multivariate analysis $(P=0 \cdot 0002)$. The same markers were significant even in the smallest sub-group analysed (the 56 ER $\alpha$-positive, tamoxifen-only cases). As shown in Table 3, ER $\beta$ variants, grade, nodal status and Ki67 were all significantly related to RFS or OS, with ER $\beta 2$ being the best predictor of OS.

\section{Discussion}

The study reported herein strongly supports the initial hypothesis that different $\operatorname{ER} \beta$ splice variants are important determinants, and hence predictors of clinical parameters including outcome, in post-menopausal women with breast cancer treated only by adjuvant hormonal manipulation. The study also confirms that individual primary breast cancers are heterogeneous with respect to the spectrum of ER $\beta$ splice variants expressed. Thus, a single breast cancer might simultaneously express different isoforms of the receptor that are potentially agonist, antagonist or unresponsive with respect to interaction with a potential inhibitor (e.g. tamoxifen). Of the three splice variants examined, expression of ER $\beta 2$ was clearly beneficial with respect to RFS (Fig. 2B). The advantage conferred by ER $\beta 5$ was less pronounced (Fig. 2C). These two variants are likely to contribute to the association of $\mathrm{ER} \beta$ with better outcome in RT-PGR studies using primers that amplify total ER $\beta$. Conversely, expression of ER $\beta 1 \mathrm{mRNA}$ apparently confers no statistically significant advantage, with respect to RFS or OS. 
In common with most previous observations, the current data reveal few associations between ER $\beta$ mRNAs and either clinical or histological features. This observation alone emphasises the complexity of the multiplicity of factors contributing to clinical behaviour and to histopathological appearances. Both grade I and III groups did have significantly higher proportions of RT-PCR-positive cases for ER $\beta 2$ when compared with grade II cases. Although not reported in other RT-PGR studies, an association of $\mathrm{ER} \beta$ protein and high grade was identified by Myoshi et al. (2001) using an antibody that is likely to be pan-variant. Others using similarly non-specific antisera (Skliris et al. 2001) have reported associations with low-grade tumours.

Unlike ER $\alpha$, which is bimodally distributed with respect to expression in breast cancers, others have reported a diverse range of $\mathrm{ER} \beta$ mRNA levels using quantitative RT-PCR (Bieche et al. 2001) making assignment of meaningful cut-off values difficult. Use of semi-quantitative RT-PGR in the manner described here imposes an arbitrary cut-off dependent on the sensitivity of the RT-PCR reaction and the detection technique. The assignment of a meaningful and valid cut-off is complex and would rely on more quantitative approaches. Despite this caveat, the use of our cut-off has distinguished statistically significant groups of cases based upon ER $\beta 2$ or ER $\beta 5$ status. Use of a higher cut-off, e.g. by reassigning the ten weakest ER $\beta 2$ RT-PCR-positive cases as negative leads to a diminished log-rank score, but a significant relationship with outcome is maintained $(P<0 \cdot 005)$. It is possible that the lack of significant association between ER $\beta 1$ and disease outcome is due, at least in part, to the technical limitations of this approach. However, the relative number of cases positive for ER $\beta 1, E R \beta 2$ and ER $\beta 5$ RT-PGR product is similar, suggesting that the distribution of ER $\beta 1$ is distinct. Despite almost half of the cases expressing all three variants, expression of ER $\beta 1$ was found to be more diverse while $\operatorname{ER} \beta 2$ and ER $\beta 5$ were more closely related.

In previous studies the relationship between ER $\beta$ and disease outcome in breast cancer patients has not been comprehensively evaluated, primarily since most early studies concentrated on the role of $\mathrm{ER} \beta$ in the wider context of breast cancer pathology. Two studies that included outcome data reported no relationship with ER $\beta$ RT-PCR (Kurebayashi et al. 2000, Bieche et al. 2001). Both studies employed non-specific RT-PGR, which has now been demonstrated to be an inferior marker to variant-specific RT-PCR. Furthermore, case selection was different such that premenopausal patients were included with no account being taken of treatment. Speirs et al. (1999a) reported increased ER $\beta$ mRNA expression in tamoxifen-resistant breast cancer patients. Again non-specific RT-PCR was used, follow-up was limited to time receiving tamoxifen and the association was based on a small number of cases $(n=17)$.

While demonstration that particular $\operatorname{ER} \beta$ splice variant mRNAs are related to disease outcome is potentially important as a molecular marker, more direct involvement in the disease process would rely on protein expression. Some relationship between ER $\beta$ expression and outcome has been reported using immunohistochemistry (Mann et al. 2001, Omoto et al. 2001, 2002, Saji et al. 2002). Nevertheless, it is difficult to compare the current RT-PCR data with immunohistological appearances; although splice variants are expressed as protein, the quantitative relationship between mRNA and protein for ER $\beta$ is not clear. Omoto et al. $(2001,2002)$ found a weak association between ER $\beta 1$ protein and better outcome, but no significant results for other variants, albeit with smaller numbers of cases from non-selective cohorts. Saji et al. (2002) found that a greater proportion of ER $\beta 2$-negative cases responded to primary tamoxifen treatment, implying an association of ER $\beta 2$ with worse response. This observation is in contrast to our current findings, but the number of cases studied was very small (18 ER $\alpha$-positive core biopsies), and it is unclear how response in this neoadjuvant setting relates to adjuvant treatment and longer-term outcome. Mann et al. (2001) studied the immunohistochemical expression of ER $\beta$ in patients treated with adjuvant tamoxifen and showed ER $\beta$-positive patients to have a better survival when compared with ER $\beta$ negative patients. Although the contribution of individual $\operatorname{ER} \beta$ variants is unclear since the employed antibody was of broad specificity, if ER $\beta 2$ expression contributes to the $\operatorname{ER} \beta$ expression measured, these findings support the current data. Recently further supportive information has emerged from a study of ER $\beta 2$ using variant-specific Western blot analysis (Palmieri et al. 2004a). Here the presence of ER $\beta 2$ was associated significantly with longer survival and with a better endocrine-treatment response. Our results indicate a stronger association 
between ER $\beta 2$ and outcome and reasons for this include differences in the patient groups studied and the method of detection for ER $\beta 2$ expression. Palmieri et al. (2004b) do not report the treatment received by the majority of patients in their study, cases included locally advanced and metastatic disease and endocrine-treatment response was evaluated in only 23 patients receiving neoadjuvant or palliative therapy. That significant associations between $\operatorname{ER} \beta 2$ and outcome or response were found is testament to the potential importance of this marker, as the authors failed to find any association between outcome and $\mathrm{ER} \alpha$ status (Palmieri et al. 2004a). Hence our results more directly address the importance of ER $\beta 2$ in the important clinical setting of adjuvant endocrine treatment, while those of Palmieri et al. suggest that ER $\beta 2$ protein expression as well as ER $\beta 2$ mRNA is related to a better outcome.

Both our findings and those of Palmieri et al. (2004a) make use of heterogeneous breast samples and it is possible that non-tumour cells contribute to the expression seen. This is potentially of some importance as it seems that, unlike $\operatorname{ER} \alpha, \operatorname{ER} \beta$ and some of its splice variants can be expressed in stromal cells of human breast (Palmieri et al. 2004b). However, using Western blots and immunostaining on the same tumour samples (Palmieri et al. 2004a) these techniques result in $>80 \%$ agreement and immunostaining is predominantly epithelial. Such results would suggest that in most cases results from heterogeneous samples reflect tumour cell expression of ER $\beta 2$, but that in situ techniques should be applied to address this issue in more detail.

Since it has been proposed that ER $\beta 2$ can act as a dominant negative regulator of $\mathrm{ER} \alpha$ (Ogawa et al. 1998), the association of ER $\beta 2$ expression with better disease outcome is not unexpected. We suggest that, in breast cancer, inhibition of ER $\alpha$ function associated with high levels of ER $\beta 2$ acts alongside tamoxifen to promote a better outcome. In summary, this study has provided new evidence to support the hypothesis that $\operatorname{ER} \beta$ splice variant expression is an important determinant of breast cancer phenotype, including response to hormonal manipulation in post-menopausal women with ER $\alpha$-positive tumours. Further studies are now required to relate expression of individual $\mathrm{ER} \beta$ isoforms to particular patterns of tumour behaviour, including response to different ER antagonists.

\section{Acknowledgements}

We wish to thank Clatterbridge Cancer Research Trust for funding this project; the Cancer Tissue Bank Research Centre for providing RNA samples and patient information; all medical professionals who contribute towards tissue bank donations and all patients who kindly donated their tissue for research use. In addition, we would like to thank Amanda Torevell and Mathew Bode (a Nuffield Science Bursary student) for technical assistance. The authors are unaware of any conflict of interest that would prejudice the impartiality of this study. The late Professor John P Sloane (University of Liverpool) was instrumental in the initiation of this work, his involvement is respectfully acknowledged.

\section{References}

Bieche I, Parfait B, Laurendeau I, Girault I, Vidaud M \& Lidereau R 2001 Quantification of estrogen receptor alpha and beta expression in sporadic breast cancer. Oncogene 20 8109-8115.

Cowley SM, Hoare S, Mosselman S \& Parker MG 1997 Estrogen receptors alpha and beta form heterodimers on DNA. Fournal of Biological Chemistry 272 19858-19862.

de Cremoux P, Tran-Perennou C, Elie C, Boudou E, Barbaroux C, Poupon MF, De Rycke Y, Asselain B \& Magdelenat H 2002 Quantitation of estradiol receptors alpha and beta and progesterone receptors in human breast tumors by real-time reverse transcription-polymerase chain reaction. Correlation with protein assays. Biochemical Pharmacology 64 507-515.

Cullen R, Maguire TM, McDermott EW, Hill AD, O'Higgins NJ \& Duffy MJ 2001 Studies on oestrogen receptor-alpha and -beta mRNA in breast cancer. European Fournal of Cancer $\mathbf{3 7}$ $1118-1122$.

Dotzlaw H, Leygue E, Watson PH \& Murphy LC 1999 Estrogen receptor-beta messenger RNA expression in human breast tumor biopsies: relationship to steroid receptor status and regulation by progestins. Cancer Research 59 529-532.

Enmark E, Pelto-Huikko M, Grandien K, Lagercrantz S, Lagercrantz J, Fried G, Nordenskjold M \& Gustafsson JA 1997 Human estrogen receptor beta-gene structure, chromosomal localization, and expression pattern. Fournal of Clinical Endocrinology and Metabolism 82 4258-4265.

Fuqua SA, Schiff R, Parra I, Moore JT, Mohsin SK, Osborne CK, Clark GM \& Allred DC 2003 Estrogen receptor beta protein in human breast cancer: correlation with clinical tumor parameters. Cancer Research $632434-2439$.

Iwao K, Miyoshi Y, Egawa C, Ikeda N \& Noguchi S $2000 a$ Quantitative analysis of estrogen receptor-beta mRNA and its variants in human breast cancers. International fournal of Cancer $\mathbf{8 8}$ 733-736.

Iwao K, Miyoshi Y, Egawa C, Ikeda N, Tsukamoto F \& Noguchi S $2000 b$ Quantitative analysis of estrogen receptor-alpha and -beta messenger RNA expression in breast carcinoma by real-time polymerase chain reaction. Cancer 89 1732-1738.

Jarvinen TA, Pelto-Huikko M, Holli K \& Isola J 2000 Estrogen receptor beta is coexpressed with ERalpha and PR and associated with nodal status, grade, and proliferation rate in breast cancer. American Fournal of Pathology 156 29-35. 
Knowlden JM, Gee JM, Robertson JF, Ellis IO \& Nicholson RI 2000 A possible divergent role for the oestrogen receptor alpha and beta subtypes in clinical breast cancer. International fournal of Cancer 89 209-212.

Kurebayashi J, Otsuki T, Kunisue H, Tanaka K, Yamamoto S \& Sonoo H 2000 Expression levels of estrogen receptor-alpha, estrogen receptor-beta, coactivators, and corepressors in breast cancer. Clinical Cancer Research 6 512-518.

Leygue E, Dotzlaw H, Watson PH \& Murphy LC 1998 Altered estrogen receptor alpha and beta messenger RNA expression during human breast tumorigenesis. Cancer Research 58 3197-3201.

Leygue E, Dotzlaw H, Watson PH \& Murphy LC 1999 Expression of estrogen receptor betal, beta2, and beta 5 messenger RNAs in human breast tissue. Cancer Research 59 1175-1179.

Locker GY 1998 Hormonal therapy of breast cancer. Cancer Treatment Reviewes 24 221-240.

Mann S, Laucirica R, Carlson N, Younes PS, Ali N, Younes A, Li Y \& Younes M 2001 Estrogen receptor beta expression in invasive breast cancer. Human Pathology 32 113-118.

Miyoshi Y, Taguchi T, Gustafsson JA \& Noguchi S 2001 Clinicopathological characteristics of estrogen receptor-betapositive human breast cancers. Fapanese Fournal of Cancer Research $\mathbf{9 2}$ 1057-1061.

Moore JT, McKee DD, Slentz-Kesler K, Moore LB, Jones SA, Horne EL, Su JL, Kliewer SA, Lehmann JM \& Willson TM 1998 Cloning and characterization of human estrogen receptor beta isoforms. Biochemical and Biophysical Research Communications $\mathbf{2 4 7}$ 75-78.

National Coordinating Group for Breast Screening Pathology 1997 Pathology Reporting in Breast Cancer Screening. NHSBSP Publication No. 3. NHSBSP Publications, NHS Breast Screening Programme, Sheffield.

Ogawa S, Inoue S, Watanabe T, Orimo A, Hosoi T, Ouchi Y \& Muramatsu M 1998 Molecular cloning and characterization of human estrogen receptor betacx: a potential inhibitor of estrogen action in human. Nucleic Acids Research 26 3505-3512.

Omoto Y, Inoue S, Ogawa S, Toyama T, Yamashita H, Muramatsu M, Kobayashi S \& Iwase H 2001 Clinical value of the wild-type estrogen receptor beta expression in breast cancer. Cancer Letters $163207-212$.

Omoto Y, Kobayashi S, Inoue S, Ogawa S, Toyama T, Yamashita H, Muramatsu M, Gustafsson JA \& Iwase H 2002 Evaluation of oestrogen receptor beta wild-type and variant protein expression, and relationship with clinicopathological factors in breast cancers. European Fournal of Cancer 38 380-386.

Palmieri C, Lam EW, Mansi J, MacDonald C, Shousha S, Madden P, Omoto Y, Sunters A, Warner M, Gustafsson JA et al. 2004a The expression of ERbetacx in human breast cancer and the relationship to endocrine therapy and survival. Clinical Cancer Research 10 2421-2428.

Palmieri C, Saji S, Sakaguchi H, Cheng G, Sunters A, O'Hare MJ, Warner M, Gustafsson JA, Coombes RG \& Lam EW $2004 b$ The expression of $\mathrm{ER} \beta$ and its variants, but not $\mathrm{ER} \alpha$, in adult human mammary fibroblasts. Fournal of Molecular Endocrinology 33 55-50.

Peng B, Lu B, Leygue E \& Murphy LC 2003 Putative functional characteristics of human estrogen receptor-beta isoforms. Fournal of Molecular Endocrinology 30 13-29.
Pertschuk LP \& Axiotis CA 1999 Steroid hormone receptor immunohistochemistry in breast cancer: past, present, and future. Breast fournal 5 3-12.

Saji S, Omoto Y, Shimizu C, Warner M, Hayashi Y, Horiguchi S, Watanabe T, Hayashi S, Gustafsson JA \& Toi M 2002 Expression of estrogen receptor (ER) (beta)cx protein in ER(alpha)-positive breast cancer: specific correlation with progesterone receptor. Cancer Research 62 4849-4853.

Saunders PT 1998 Oestrogen receptor beta (ER beta). Reviewes of Reproduction 3 164-171.

Saunders PT, Millar MR, Macpherson S, Irvine DS, Groome NP, Evans LR, Sharpe RM \& Scobie GA 2002 ERbetal and the ERbeta2 splice variant (ERbetacx/beta2) are expressed in distinct cell populations in the adult human testis. Fournal of Clinical Endocrinology and Metabolism 87 2706-2715.

Shaaban AM, Sloane JP, West CR \& Foster CS 2002 Breast cancer risk in usual ductal hyperplasia is defined by estrogen receptor-alpha and Ki-67 expression. American Fournal of Pathology $160597-604$.

Shaaban AM, O'Neill PA, Davies MP, Sibson R, West CR, Smith PH \& Foster CS $2003 a$ Declining estrogen receptorbeta expression defines malignant progression of human breast neoplasia. American Foumal of Surgical Pathology 27 $1502-1512$.

Shaaban AM, O'Neill P \& Foster CS $2003 b$ Re: Skliris et al. Evaluation of seven oestrogen receptor beta antibodies for immunohistochemistry, Western blotting, and flow cytometry in human breast tissue (Fournal of Pathology 2002196 155-162). Fournal of Pathology 199130.

Skliris GP, Carder PJ, Lansdown MR \& Speirs V 2001 Immunohistochemical detection of ERbeta in breast cancer: towards more detailed receptor profiling? British Fournal of Cancer 84 1095-1098.

Speirs V \& Kerin MJ 2000 Prognostic significance of oestrogen receptor beta in breast cancer. British Fournal of Surgery $\mathbf{8 7}$ 405-409.

Speirs V, Malone C, Walton DS, Kerin MJ \& Atkin SL $1999 a$ Increased expression of estrogen receptor beta mRNA in tamoxifen-resistant breast cancer patients. Cancer Research $\mathbf{5 9}$ $5421-5424$

Speirs V, Parkes AT, Kerin MJ, Walton DS, Carleton PJ, Fox JN \& Atkin SL 1999b Coexpression of estrogen receptor alpha and beta: poor prognostic factors in human breast cancer? Cancer Research $\mathbf{5 9}$ 525-528.

Tong D, Schuster E, Seifert M, Czerwenka K, Leodolte S \& Zeillinger R 2002 Expression of estrogen receptor beta isoforms in human breast cancer tissues and cell lines. Breast Cancer Research and Treatment 71 249-255.

Vladusic EA, Hornby AE, Guerra-Vladusic F \& Lupu R 1998 Expression of estrogen receptor beta messenger RNA variant in breast cancer. Cancer Research 58 210-214.

Received 21 July 2004

Accepted 12 August 2004

Made available online as an

Accepted Preprint 24 August 2004 